\title{
ISLAM IN THE STATE SECURITY POLICY OF MUSLIM COUNTRIES: PROBLEMS AND TRENDS
}

\author{
Oleksandr Aulin ${ }^{1}$ \\ ${ }^{1}$ Ph.D. (Philosophy), Associate Professor of Foreign Languages and General Disciplines department, KROK \\ University, Kyiv, Ukraine, e-mail: sozionik@gmail.com, ORCID: http: orcid.org/0000-0001-7304-7182
}

\begin{abstract}
The relevance of the article is that today more and more countries are suffering from terrorist attacks and other manifestations of religious and ethnic intolerance. The purpose of the article is to analyze the security sector of the state policy of the leading Muslim countries on Islam with the identification of the most successful approaches that can be used by the state authorities to prevent the manifestations of radical Islamism in Ukraine. Based on the objectives of the study, methods of system analysis, structural-functional and analogy method in public administration were used. As a result, the structural features of the securitization of Islam, as well as the conditions and principles of its application in the public policy of leading Muslim countries. Causal links have been established that have influenced the need to counter radical Islamism. The main ways to solve the problem are identified, taking into account the relationships and structuralfunctional features of the environment identified during the study. Biggest part of such actions is carried out by supporters of Islam, a significant number of whom also live in modern Ukraine. In this context, it is important to have an objective view of the situation in Muslim communities, where radical Islamists make up a small percentage and, moreover, have a big number of opponents. Most often they are public authorities. The security policy of Muslim states is twofold. First, measures are taken to spread their influence abroad by disseminating their own interpretation of the holy Islamic books, while leveling similar activities by other Muslim countries in their information space. Second, countering local radical Islamism in the system of state security policy is ensured through the securitization of Islam. Measures to securitize Islam in leading Muslim countries are systemic, well-coordinated, and use all available resources. In order to improve Ukraine's state policy on Islam, the most effective practices of securitization of Islam, tested in the leading Muslim countries, have been proposed.
\end{abstract}

Keywords: public policy, securitization of Islam, government agencies, government, radical Islamists, Salafists, ideology

JEL Classification: D73, D78

Formulas: 0; fig.: 0; tabl.: 0; bibl.: 12

Introduction. The last decades of the twentieth century in the Muslim world were held under the auspices of the Islamic revival. Representatives of the reform movement in Islam, the Islamists, played an important role in this process. Emerging in response to Western expansion, the Islamist movement has gathered many dissatisfied people in a short time through its own interpretation of sacred texts and the declarative commitment of the "righteous predecessors" way of life. Some of the latter followed radical Islamists. After the victories over the Soviet Union in Afghanistan, the seizure of power in Iran, participation in the Israel resistance in Palestine, the latter realized themselves with great force. Starting with the New York terrorist attacks in September 2001 and ending with the creation of the so-called "Islamic State", radical Islamists have tried to become a global player in the world. It was from this time that the situation began to develop, which led to the fact that as of June 2020, 97\% of terrorist organizations on the UN Security Council's sanctions list were Muslim. Today, Islamist radicalism affects not only European countries. According to their own dogma, radical Islamists must exterminate (apart from 
adherents of other religions) those Muslims whom they themselves declare to be infidels. Muslim governments, which Islamists see as pursuing unjust and generally "wrong" policies, are also subject to removal. Of course, the government of many Muslim countries is trying to counter radical Islamists. To this end, Islamic securitization measures are often used. Given the presence of a large number of Muslims among the population of Ukraine, the study of the above experience of Muslim countries becomes quite relevant for modern Ukrainian government.

Literature Review. The works of A. Kondral and G. Kosach are devoted to the study of problems related to the ideology of radical Islamist movements. Other forms of Islamic activism, in particular in the Salafi and Wahhabion environment, their theoretical and ideological foundations are analyzed by D. Brylov and O. Yarosh. Socio-cultural and religious-legal features of Sub-Saharan Africa are considered by N. Prorochenko. A. Aydintashbash studies the trends of modern Turkish foreign policy, using a comparative methodology. A. Dedok devoted his research to the "Organization of the People's Mujahideen of Iran." Representatives of the Copenhagen school B. Buzan, O. Wever, J. de Wilde developed conceptual principles of securitization, as well as desecuritization. However, today there are no works that would consider the Islamic factor as an object of state security policy of Muslim countries, in relation to modern Ukrainian realities.

Aims. The purpose of the article is to analyze the security sector of the state policy of the leading Muslim countries on Islam with the identification of the most successful approaches that can be used by the state authorities to prevent the manifestations of radical Islamism in Ukraine.

Methods. Based on the objectives of the study, methods of system analysis, structural-functional and analogy method in public administration were used. As a result, the structural features of the securitization of Islam, as well as the conditions and principles of its application in the public policy of leading Muslim countries. Causal links have been established that have influenced the need to counter radical Islamism. The main ways to solve the problem are identified, taking into account the relationships and structural-functional features of the environment identified during the study.

Results. It has been found that in Muslim countries, security issues related to Islam are viewed in terms of internal and external functionality. The latter has the form of a binary opposition. On the one hand, a positive image of the state power, which governs the country in the spirit of Islam, is formed to influence other Muslim countries. On the other hand, such influences are counteracted from the outside. The main internal problem is local radical Islamism. Islamism is a reform movement based on the so-called Salafism (own interpretation of the political and religious heritage of "righteous predecessors"), the ideology of the "Muslim Brotherhood", according to which Muslim society can use similar Western democratic norms, but while maintaining Islamic principles and values, in particular the rule of Sharia (Kondral), in radical manifestations - takfirism (accusation of unbelief) and jihadism - a misinterpretation of jihad (Aulin, Brilov, Prorochenko, \&Yarosh, 2019, p. 73). 
Islamism is a reform movement based on the so-called Salafism (own interpretation of the political and religious heritage of "righteous predecessors"), the ideology of the "Muslim Brotherhood", according to which Muslim society can use similar Western democratic norms, but while maintaining Islamic principles. and values, in particular the rule of Sharia (Kondral), in radical manifestations - takfirism (accusation of unbelief) and jihadism - a misinterpretation of jihad (Buzan, Weaver, $\&$ Wilde, 1998). However, it should be taken into consideration that in the case of Islam, force is envisaged only in the context of the securitization of the activities of extremely radical jihadist Islamists. In the fight against them are usually used force resources of special services, special police and army units. Securitization is also influenced by other Muslim states from abroad. In this case, not only discursive but also forceful practices are used against their supporters in the middle of the country. In structural terms, the main substantial element of measures of influence or counterinfluence is the narrative, which is mostly disseminated through local and foreign media. If we consider the situation in the most developed Muslim countries, in addition to the above general points are striking features.

Thus, the domestic policy of the Kingdom of Saudi Arabia (KSA) is aimed at the selective securitization of Islam. In the "outer" segment, the main narrative revolves around the role of the King of Saudi Arabia as the "Servant of the Two Shrines" (Mecca and Medina), which is an indicator of Arab supremacy in Islamic doctrine and a latent call to other Muslim states to submit to Riyadh. In the "internal" segment, the narrative is aimed at identifying the danger to the state and society from opposition Islam. In addition to the traditional use of the media, specific propaganda tools such as religious treatises are used in state information policy. The most famous of them was "The One Who Watches" by M.M. Al-Mirsal. The treatise was published and distributed with the assistance of The Ministry of Islamic Affairs, Dawah and Guidance of Saudi Arabia and summarized the activities of local official theologians in refuting the arguments of anti-systemic opposition ideologists. The religious and ideological constructions of the opposition were usually leveled with arguments based on the appropriate interpretation of the texts of the Qur'an or Sunnah (Kosach). Another powerful tool of state information policy is the institution of fatwas, the solution of important problems on the base of Sharia by authorized theologians. Control in this area is exercised by the state body, the Senior Council of Ulema.

Turkey's leadership of the KSA in Sunni Islam is disputed by Turkey. After the rise to power of moderate Islamists led by current President Recep Tayyip Erdogan, Ankara began to use the doctrine of neo-Ottomanism in its foreign policy. According to her, Turkey is trying to expand its political and economic influence in the territories that were formerly part of the Ottoman Empire. At the same time, until the mid-2000s, radical Islamists were most active in the TR. Their main goal was to forcibly change the secular regime to a Sharia one. Unlike Riyadh, Ankara does not distribute religious treatises, but also actively uses the institution of fatwas. The distribution of the latter is controlled by a specially authorized state body - the Directorate of Religious Affairs (Diyanet). The state security policy towards Islam is based on intensive use of media opportunities. An example is the publication of the 
need for the Turkish armed forces to create a buffer zone in northern Syria to prevent the entry of Kurdish and other terrorists into Turkey (Aydintasbas).

The features of the state power of another contender for the role of Islamic leader - Iran are largely due to the developed concept of Ayatollah Khomeini "concept of the province of al-Faqih" (the reign of the scientist - theologian). After the overthrow of the Shah's regime in Iran, Ayatollah Khomeini was opposed by the Marxist-Islamist movement " The People's Mujahedin Organization of Iran" (PMOI). After the PMOI fighting units were driven out of IRI territory, they were used by Iraq against the Iranian military. In response, thousands of PMOI supporters were executed in Iran. Gradually, PMOI moved away from Marxism in its ideology towards liberalism and began to focus on the West (Dedok). In the form of a threat to the state and society in modern Iran, the image of PMOI as enemy mercenaries is being formed. This corresponds to the main narrative, which is based on the position of Ayatollah Khomenay that today there is neither Shiite nor Sunni Islam, but there is real Islam and terrorist Islam - American (Khomenai). A similar position is broadcast by the Iranian media both in the country and abroad. At the same time, relevant statements by government officials and diplomats are being disseminated, in particular through "friendly" Russian and other media. Fatwas play an important role in IRI's state information policy, especially when they are authored by Iran's religious leader.

Without claiming leadership among Sunnis, due to its very small human and all but financial and information resources, Qatar plays a very prominent role in the Arab world. Doha is one of the main sponsors of the Muslim Brotherhood, and has a powerful and very authoritative information resource, Al Jazeera, in Islamic countries. Like other political and religious centers, Qatar's state information policy is aimed at the selective securitization of Islam. This easily demonstrates the acquaintance with the materials of $\mathrm{Al}$ Jazeera. In them, the attitude towards Islamists varies from neutral to positive (Younes). Al Jazeera, on the other hand, is actively criticizing the Salafi regime in Saudi Arabia (Beydoun). Using significant influence on Al Jazeera's Arab audience, Doha is trying to discredit "Salafi-Wahhabi" Islam in the KSA. Demonstrate links with terrorist jihadists and thus remove them from the field of political discourse into the possible use of force.

Since Egypt's first independent leader, President Gamal Nasser, power struggles in the country have been between the (former) military and the older international Islamist Muslim Brotherhood. After that, the representative of the "Muslim Brotherhood" Mohammed Morsi won the election of the President of the Arab Republic of Egypt (ARE), the Egyptian military carried out another military coup and the country was led by a protege of the army Abdul-Fattah al-Sisi. The new leader has continued to pursue the securitization of Islam. Within the framework of the latter, in contrast to other countries, the state authorities of Egypt effectively use the information capabilities of the authoritative theological institution in the Islamic world - Al-Azhar University (Faradzhallah). In general, The Ministry of Awqaf of Egypt controls the activities in this area by the state. 
In the largest Muslim country with the largest population and with the highest GDP - Indonesia, just several years ago multimillion rallies of congresses of Islamists - supporters of the international Islamist party "Hizb ut-Tahrir al-Islami" have taken place. In 2017, according to a presidential decree circulated in local and foreign media, with the statement "for the protection of national unity", the party's activities were banned (Topsfield, Rompies).

In modern Ukraine there is no coordinated state information policy in the field of securitization of Islam. The Department for Religions and Nationalities of the Ministry of Culture of Ukraine does not have a separate unit and experts to work on this topic. Experts are scattered among various scientific and research institutions. This complicates the work of law enforcement agencies in this direction and allows Islamists to spread the views of their ideologists, not only moderate, but also close to the radical sense, almost without hindrance. In the future, such an approach could lead to serious problems, including the emergence of some negativity in relations with European partners.

Discussion. The absence of a unified state security policy towards Islam in modern Ukraine will continue to create problems in the activities of law enforcement agencies aimed at counteracting the spread of radical Islamism. Today, local Islamists are almost free to disseminate information materials of foreign, including radical, ideological centers. While maintaining such approaches in security policy, it is possible to create a radical Islamist infrastructure in Ukraine in the future. Against the background of periodic terrorist acts committed by Islamist jihadists in the European Union, Ukraine may in the future experience not only image but also more serious political problems on the path to European integration. In addition, there is no single authorized state body to address the problem. It is necessary to create an institution of Islamic securitization, organize and conduct work in this area at the system level.

Conclusion. The main reasons for the securitization of Islam are the activities of Islamist movements (primarily radical), as well as foreign information and ideological influences. At the same time, Islam plays an important role in the sociopolitical sphere of Muslim countries. As a result, there is a selective securitization of Islam in these countries, which can be divided into two parts - internal and external. In the domestic segment, there is a rather strict securitization of local radical Islam, removing the situation from the political field of decision-making. In the external segment, the main efforts are aimed at leveling foreign political and religious influences.

The state information policy of the leading Muslim countries in the field of securitization of Islam is characterized by the integrated use of state, religious and public resources. Due to this, the relevant narratives are widely disseminated within and outside the countries through the coordinated use of local and foreign media, religious and political resources, under the leadership of state coordinating bodies.

In modern Ukraine, there is no coordinated state information policy in the field of securitization of Islam, which allows Islamists to spread their own ideology almost without hindrance. Such an approach could lead to more serious problems in the future than even the emergence of some negativity in relations with European 
partners. To prevent this, it is proposed to implement the following measures. First, to create a specialized institution to coordinate activities in the field of securitization of radical Islam. Secondly, to develop a program of actions aimed at preventing the manifestations of Islamist radicalism in Ukraine with the involvement of relevant experts. Third, to provide state support to Muslim organizations that oppose Islamists in order to make more effective use of their religious, informational, educational and other opportunities in the information and ideological confrontation with Islamists.

\section{References:}

1. Aulin O.A., Brilov D.V., Prorochenko N.O., Yarosh O.A. (2019). Islam i politika: ideologiya, ruhi, organizaciyi [Islam and politics: ideology, movements, organizations]. Kyiv: DEONIS PLUS Ltd

2. Aslı Aydıntaşbaş (2018). Kendi elimizle Afganistan kuruyoruz Retrieved from https://www.cumhuriyet.com.tr/koseyazisi/948171/Kendi_elimizle_Afganistan_kuruyoruz.html

3. Khaled A. Beydoun (2018). The Saudi regime does not represent Islam. Retrieved from https://www.aljazeera.com/opinions/2018/10/20/the-saudi-regime-does-not-represent-islam/

4. Barry Buzan, Ole Weaver, Jaap de Wilde (1998). Security: A New Framework for Analysis. Boulder, CO: Lynne Rienner

5. Dedok N. (2019). Narodnye modzhahedy «Mudzhahidin Halk» [People's Mujahideen "Mujahideen Hulk"]. Moscow, St. Petersburg: Samoopredelenie. Retrieved from https://avtonom.org/freenews/ narodnyemodzhahedy-mudzhahidin-halk-novaya-kniga-izdatelstva-samoopredelenie

6. 6. M. Faradzhallah (2014). Ministerstvo po delam religii Egipta i universitet «Al-Azhar» ne imeyut otnosheniya k VAOO «Alraid» [Egyptian Ministry of Religious Affairs and Al-Azhar University have nothing to do with AJSC Alraid]. Retrieved from http://arab.com.ua/ru/news/132905

7. A.A. Kondral (2020). Koncepciya gosudarstvennogo upravleniya v ideologii associacii «Bratevmusulman» [The concept of public administration in the ideology of the Muslim Brotherhood Association]. Retrieved from https://www.researchgate.net/publication/342354479 Koncepcia gosudarstvennogo upravlenia v ideologii _associacii_Bratev-musulman

8. Kosach G. (2013). Saudovskaya Araviya: vlast, ulemy i antisistemnaya oppoziciya [Kosach G. Saudi Arabia: Power, Ulema and Anti-System Opposition]. Retrieved from https://cyberleninka.ru/article/n/saudovskaya-araviya-vlast-ulemy-i-antisistemnaya-oppozitsiyabogoslovsko-politicheskiy-otvet-protivnikam-rezhima/

9. Ali Hosseini Khamenei (2015). Leader's Speeches in 26th commemoration ceremony of Imam Khomeini. Retrieved from http://en.imam-khomeini.ir/en/c103 11963/egallery/Leader_s_Speeches_in_26th_commemoration_ceremony_of_Imam_Khomeini/page20.

10.Ali Younes (2016). Jordan's Islamists hopeful about making electoral gains. Retrieved from https://www.aljazeera.com/news/2016/9/20/jordans-islamists- hopeful- about-making-electoral-gains.

11.Jewel Topsfield, Karuni Rompies (2017). Indonesia bans Islamic organisation Hizbut Tahrir to protect Pancasila. Retrieved from https://www.smh.com.au/world/i ndonesia-bans-islamic-organisation-hizbuttahrir-to-protect-pluralism-20170719-gxeaae.html.

12.Mawlood, S. (2020). Global view of the main reasons terrorism emergence. Public Administration and Law Review, (3), 95-108. https://doi.org/10.36690/2674-5216-2020-3-95 